\title{
Effect of Smart Phone Use on Handgrip Strength and Fatigue in Female College Students
}

\author{
SAMIHA M. ABELKADER, Ph.D. \\ The Department of Rehabilitation Health Sciences, College of Applied Medical Sciences, King Saud University, \\ Kingdom of Saudi Arabia
}

\begin{abstract}
Background: Smart phone is a device that combines mobile and cellular functions in one unit. Many smart phone users spend hours on the irphones every day that require esprolonged grips, repetitive motion on small buttons and awkwardwrist movement leading to hand, wrist and arm ailments.

Aim of Study: To investigate the effect of smartphone overuse on handgrip strength.

Material and Methods: One hundred and eighty-eight female college students of King Saud University were included in the study. The study was conducted between June 2016 and December 2018. They were divided into two groups: Smartphone users $(n=103)$ and non-smartphone users $(n=85)$, between the agerange, 18-25 years, were included. Their handgrip strength was measured usinga handheld dynamometer. Participants performed three maximum at tempts for each measurement, and the average value of three trials was taken. A few seconds of rest were given between each trial tominimize fatigue. We analyzed the difference between the groups using paired $t$-test.
\end{abstract}

Results: No significant difference was found between theright and left hand's grip strengthson both groups $(p>0.05)$. The fatigue evalues were also not significantly different $(p>0.05)$. The significance level was set at $p \leq 0.05$.

Conclusion: High-frequency smartphone use did not affect the grip strength in female college students.

Key Words: Grip strength-Smartphone - Overuse.

\section{Introduction}

A SMART phone is aninte grate dphone for all your data andvoice needs, short message system (SMS), fast and easy emailing, browser and organizer applications. The typing is easier because it comes with aminiature keyboard, "aninnovative keyboard technology that supports the advanced messaging features that serious users require" [1]

Correspondence to: Dr. Samiha Abdelkader, E-Mail: sabdelkader@ksu.edu.sa
The number of smart phone users has dramatically increased [2]. More than half of the teenage users are addicted to their smartphones [3]. Smart phone is designed and structured that need both hands to operate, but young adults prefer to use it with one hand [4]. Prolonged use of the small screen and the tiny 'qwerty' keyboard areas sociated with muscul oskeletal disorders and temporary visual fatigue. The tiny keypad requires small repetitive emovements, usually carried out with the thumbs. The thumbs are not designed for repetitive dexterous movements, result ingin fatigue and discomfort if not controlled [4].

Hand grip streng this referring to the muscular strengt hand for cethatcanbe generated with the hand. A handgrip's strength is the result of forceful flexion of all finger joints, thumbs, and wrist swith the maximum voluntary for cethat the subject can exert under normal conditions $[\mathbf{5 , 6}]$. Many daily functions and sporting events require high activity levels of the forearms and hands' flexor musculature, and grip strength is essential.Grip strength may also play a role in injury prevention and rehabilitation. High-frequency use of electronic devices, such as smart phones, iPods,could lead tomusculo skeletal problems as handheld electronics may require prolonged grips, repetitive motionon small buttons and awk ward wrist movements [7]. These are referred to as over use injuries or repetitive strain injuries (RSI) because of insufficient recovery time between demands and highfrequency use of smart phones. The cumulative effect of stress on the region causes them echanicalor chemical activation of pain and loss of grips trength, weakness orfatigue [8]. Also, excessive use of smartphones may cause vision problems. These complications may affect hand functionality, ultimately reduces the quality of life [9]. We hypothesized that smartphone users' overuse would 
have less grip strength and more fatigue than the non-smartphone users. This study aimed to investigate the effect of smartphone use on grip strength and fatigue in college females.

\section{Material and Methods}

Study protocol: This was a cross-sectional comparative study involving 188 females' students, of which 103 were smart phone users and 85 were non-smartphone users with less frequent use. All the participants were recruited as a convenient sample from King Saud University. The age of the respondents ranged between 18-25 years. All the participants were invited to participate voluntarily in the study. Healthy females who have been using smart phones for more than six months for at least 4 hours a day were considered smartphone users. People who do not use smartphones or less than 4 hours a day were included as non-smartphone users. Females with any history of muscul oskeletal problems, trauma, hand or shoulder surgery were excluded.

\section{Instrumentation:}

Anthropometric measurements such as height and weight were measured with minimal clothing. A handheld dynamometer (Grip track commander, German J-Techp) was used to measure grip strength. A visual analogue scale (VAS) scale was used to assess for any pain during the protocol. All measurements were obtained at the same time of the day, between 8:00 am and 2:00 pm.

\section{Procedure:}

The participants were seated, with the should eradducted and neutrally rotated, elbow flexed at 90 degrees, for earmina neutral position, and the wrist between 0 and $30^{\circ}$ extension and between 0 and $15^{\circ}$ ulnar deviations. In all cases, the arm should not be supported. The dynamometer is presented vertically and in line with the for earmtomainta in the standard for earm and wrist positions. All measurements were performed for both right and left hands. Subjects performed three maximumat tempts for each measurement, and the average value of these trials was recorded (strength). A few second rests gave (5-10) between each trial tominimize fatigue effects.

Fatigue shows the reduction in force at the end of the test compared to the maximum for cereached during the test. For example, if the maximum fo rcer each is 100lb. and the for ceat the end of the test is $80 \mathrm{lb}$., the fatigueis $20 \%$. The patients were given standar dinstructions and verbal prompts such as "I want you to hold the hand leand squeezea shardas you can". The position and procedure were demon strated before taking the test. After the patientis positioned appropriately, the patient was asked if she was ready and to squeeze a shard as she can". We gave verbal commands like "Harder! Harder! Relax!" and the test is repeated three times for both hands.

\section{Data analysis:}

Statistical package for social sciences (IBM for statistics, SPSS, version 16) wasused to analyze the data. Descriptive statistics like mean, the standard deviation was used for demographic variables. A paired $t$-test was used to analyze between-group differences in grip strength and fatigue and between the right and left hands.

\section{Results}

A total of 188 participants were included and analyzed for the study, out of which 103 were smartphone users, and 85 were non-smartphone users. The demographic variables like age, height and weight were analyzed. There was no statistically significant difference in the demographic variables between the groups (Table 1).

Table (1): Participants characteristics.

\begin{tabular}{lccc}
\hline Variables & $\begin{array}{c}\text { Non-smartphone } \\
\text { users }\end{array}$ & $\begin{array}{c}\text { Smartphone } \\
\text { users }\end{array}$ & $\begin{array}{c}p \text { - } \\
\text { value }\end{array}$ \\
\hline Age (years) & $21.74 \pm 1.73$ & $20 \pm 2.4$ & 0.007 \\
Height (centimeters) & $159 \pm 6.3$ & $161 \pm 5$ & 0.006 \\
Weight (kilograms) & $60 \pm 12$ & $59 \pm 11.48$ & 0.007 \\
\hline
\end{tabular}

${ }^{*} p>0.05$, no statistically significant difference.

The handgrip strength for the right and left handsin Non-smartphone users was $45.4 \pm 11.4$ and $42 \pm 11.95$, and for smartphone users was $45.5 \pm 9.46$, 41.2 \pm 9.8 . (Table 2). When the two groups' overall data were evaluated, A statistically, no significant difference was found between the grip strengths of the right and left hand on both groups $(p>0.05)$. The fatigue values were also not significantly different.

Table (2): Comparisonof grip strength and fatigue betweenthegroups.

\begin{tabular}{lccc}
\hline Variables & $\begin{array}{c}\text { Non-smartphone } \\
\text { users }\end{array}$ & $\begin{array}{c}\text { Smartphone } \\
\text { users }\end{array}$ & $\begin{array}{c}p \text { - } \\
\text { value }\end{array}$ \\
\hline Grip strength: & & & \\
$\quad$ Right & $45.4 \pm 11.4$ & $45.5 \pm 9.46$ & $0.8951^{*}$ \\
$\quad$ Left & $42 \pm 11.95$ & $41.2 \pm 9.8$ & $0.6115^{*}$ \\
Fatigue: & & & \\
$\quad$ Right & $6.7 \pm 4.79$ & $7.9 \pm 4.9$ & $0.0958^{*}$ \\
Left & $7 \pm 3.66$ & $7.7 \pm 4.2$ & $0.2438^{*}$ \\
\hline
\end{tabular}

${ }^{*} p>0.05$, no statistically significant difference. 


\section{Discussion}

The purpose of our study was to investigate the effect of over use of the smartphone on handgrip strength. The results showed no significant difference in the handgrip strength between the user and the smartphone's non-user.

The current study results are similar to the previous study findings showing that overuse of handheld devices does not affect the hand's grip strength [10]. However, they found that overuse of smartphones was associated with weaker ulnar nerve conduction velocity, worse neck pain, and reduced forward head angle movement. Similar to our study methods, Samaan et al., also compared between high and low frequency of smartphone use. The participants were divided into two groups based on the number of hours ( $>4$ hours/day)of mobile use. Our study did not assess the conduction velocities, and we assessed only the grip strength difference between the high-frequency and lowfrequency users. In contrast to our study findings, another study compared two adults' groups over smartphone overuse (high, low) and found that high-frequency smartphone users had decreased pinch strength and hand functions compared to low-frequency smartphone users [11,12]. However, interventional studies investigating the factors to reduce smartphone use were limited [13]

It is also important to note the fatigue during the handgrip measurements. In our study, only physical or peripheral fatigue was measured. We also found no statistical difference between the high and low-frequency users. The neuromuscular junction changesandless able to generate the contractile forceresult in peripheral fatigue $[\mathbf{1 4 , 1 5 , 1 6}]$ The possible explanation for not observing any difference between the groups in grip strength could be: Many factors affect the handgrip strength, such as the level of activity, sports participation, regular exercise and the type of work and occupation $[9,17]$. All the factors were not analyzed in our study, which might have led to our findings. Hence, future studies should investigate the factors that might influence handgrip strength. Also, $80 \%$ of Saudi Arabian women own a smartphone, and 99.1\% use the internet to browse [18]. There are a few limitations in our study worth mentioning. We included only a convenient sample and only females. Secondly, our sample size is small to investigate any difference between the groups.

\section{Conclusion:}

The frequency of smartphone use may not affect the handgrip strength in college females. Studies assessing the factors that affect the handgrip strength are needed in future.

\section{References}

1- OSAILAN A.: The relationship between smartphone usage duration (using smartphone's ability to monitor screen time) with handgrip and pinch-grip strength among young people: An observational study. BMC Musculoskelet Disord, 22: 186, 2021.

2- How Many People Have Smartphones in 2020? Available from: smartphones\#: :text=Latest figures show an increasingrate is at 45.4_\%. Accessed 15 Oct, 2020.

3- WALLACE K.: Half of teens think they're addicted to their smartphones. CNN, Turn Broadcast. 2016. https://edition.cnn.com/2016/05/03/health/teens-cell-phoneaddiction-parents/index.html . Accessed 03 Mar, 2021.

4- KARLSON A.K., BEDERSON B.B. and CONTRERASVIDAL J.: Understanding single-handed mobile device interaction. Hand Res. user interface Des Eval Mob. Technol., 1: 86-101, 2006.

5- RADWAN N.L., IBRAHIM M.M. and MAHMOUD WSE-D.: Evaluating hand performance and strength in children with high rates of smartphone usage: An observational study. J. Phys. Ther. Sci., 32 (1): 65-71, 2020.

6- MALINA R.M., ZAVALETA A.N. and LITTLE B.B.: Body Size, Fatness, and Leanness Of Mexican American Children In Brownsville, Texas: Changes Between 1972 and 1983. American Journal of Public Health, 77 (5): 573-577, 1987.

7- BEROLO S., WELLS R.P. and AMICK B.C III.: Musculoskeletal symptoms among mobile handheld device users and their relationship to device use: A preliminary study in a Canadian university population. Appl. Ergon., 42 (2): 371-8, 2011

8- PERAMAN R. and PARASURAMAN S.: Mobile phone mania: Arising global threat in public health. J. Nat. Sci. Biol. Med., 7 (2): 198-200, 2016.

9- SHOUKAT S.: Cell phone addiction and psychological and physiological health in adolescents. EXCLI J., 18 47-50, 2019.

10- SAMAAN M., ELNEGMY E., ELNAHHAS A. and HENDAWY A.S.: Effect of prolonged smartphone use on cervical spine and hand grip strength in adolescence. Int. J. Multidiscip Res. Dev., 5: 49-53, 2018.

11- INAL E.E., DEMIRCI K., ÇETINTÜRK A., AKGÖNÜL M. and SAVAS S.: Effects of smartphone overuse on hand function, pinch strength, and the median nerve. Muscle Nerve, 52 (2): 183-8, 2015.

12- BUDOFF J.E.: The prevalence of rotator cuff weakness in patients with injured hands. The Journal of Hand Surgery, 29 (6): 1154-1159, 2004.

13- TIDKE S.B., SHAH M.R. and KOTHARI P.H.: Effects of Smartphone Addiction on Pinch Grip Strength. Int. J. Heal Sci. Res., 9 (10): 79-82, 2019.

14- FERNANDES A., DE A., BRITO, VIEIRA C.J. and MARINS B.C. J.C.B.: Effect of peripheral muscle fatigue during the testing of handgrip strength. Fisioterem Mov., 27 (3): 407-12, 2014. 
15- WAN J., QIN Z., WANG P., SUN Y. and LIU X.: Muscle fatigue: General understanding and treatment. Exp. Mol. Med., 49 (10): e384-4, 2017.

16- ABDELHAMEED A.A. and ABDEL-AZIEM A.A.: Exercise training and postural correction improve upper extremity symptoms among touchscreen smartphone users. Hong Kong Physiother J., 35: 37-44, 2016.

17- HAIDERS., LUGERE., KAPAN A., TITZE S., LACKINGERC., SCHINDLER K.E. and DORNER T.E.: Asso- ciations between daily physical activity, handgrip strength, muscle mass, physical performance and quality of life in prefrail and frail community-dwelling older adults. Quality of Life Research, 25 (12): 3129-3138, 2016.

18- ALOTAIBI H.J.: Foresightful strategic planning and organisational flexibility in the saudi telecommunications sector under turbulent economic conditions. International Journal of Advanced Research in Management and Social Sciences, 8 (11): 114-134, 2019.

\section{تأ ثير استخدام الهاتف الذكى والوى على قوة قبضة اليد والاجهاد لدى طالبات الجئ الجامعة}

خلفية الدراسة وهدفها: الهاتف الذكى هو جهاز يجمع بين وظائف المحمول والخلوى فى وحدة واحدة. يقضى العديد من مستخدمى.

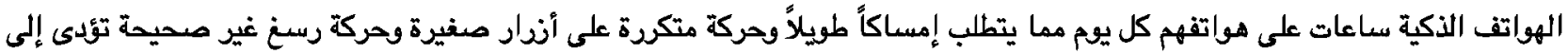
أمراض اليد والرسيغ والذراع. الهدف من الدراسةة: فحص تأثتير الإفراط فى استخدام الهاتف الذكى على قوة قبضة اليد.

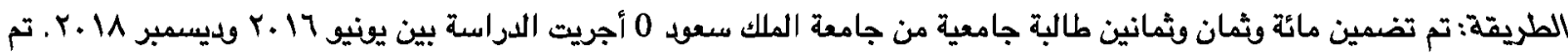

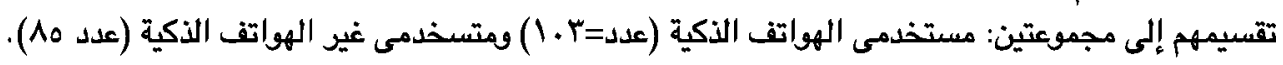

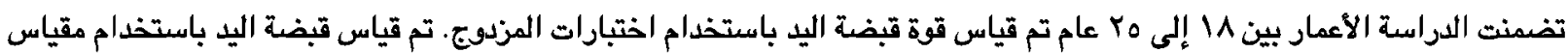

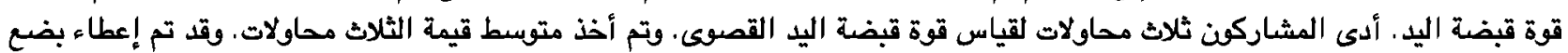

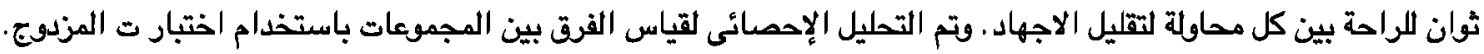
النتائج : لم يتم إيجاد فرق ملحوظ بين قوة قبضة اليد اليمنى واليسرى فى كلاً المجموعتين. وقد وجد أيضاً أن القرق في قيم الاجهاد غير 